\section{THE WILD HORSE OF POLAND}

\section{By T. JANIKOWSKI \\ Formerly of Warsaw}

W HILE studying the literature of the fossil remains of Scottish prehistoric animals I came across many interesting data recorded by the eminent Edinburgh zoologist, Prof. J. Cossar Ewart, on the subject of the hypothetical wild 'forest horse' of Scotland. According to Ewart it must have been "a stout horse with a heavy mane and tail, short strong legs, thick fetlock, joints and hoofs", a "type to which belong many of the stout, shortnecked, round. quartered, deerstalking ponies of the Scottish Highlands", with a face that is "broader and at the same time shorter... the outline of the face being concave". Until recently, the existence of such an animal, either in the history of man or in prehistoric times, lacked satisfactory proof. In view of the uncertainty concerning the Scottish 'forest horse' I should like to record certain facts about an interesting type of horse which still exists in Poland. This horse, the so-called konik (literally 'little horse' or 'pony'), formed the subject of an extensive study by Prof. T. Vetulani, of the University of
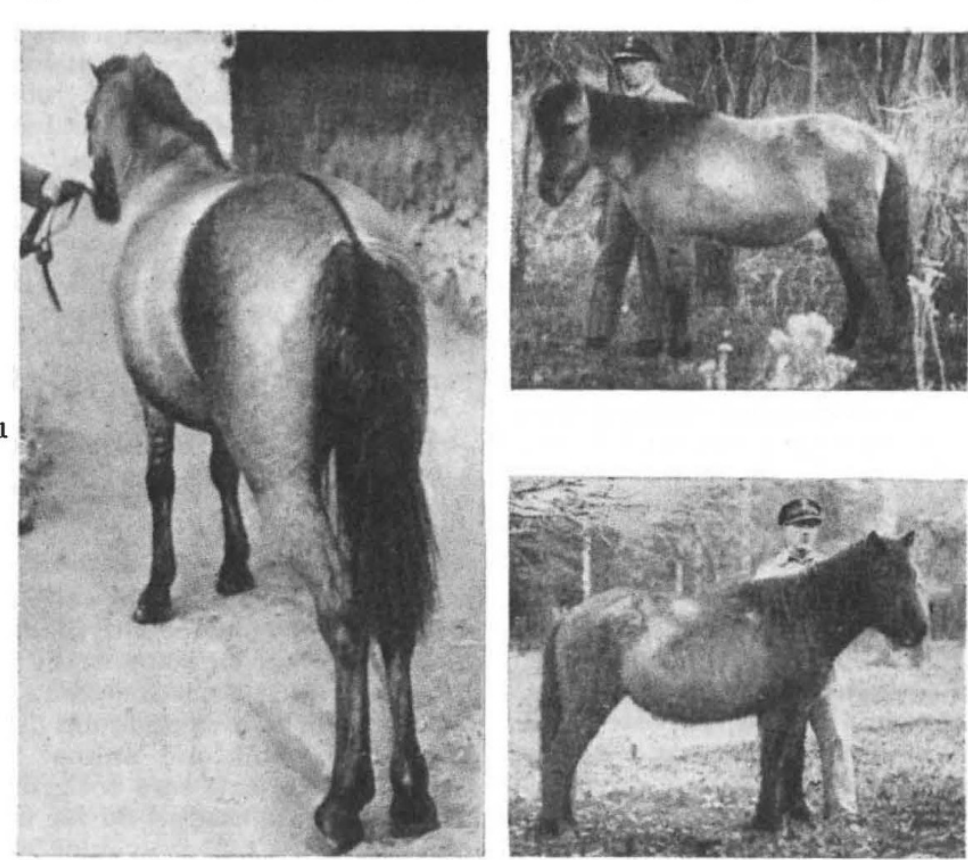

profile of the skull, a face which is remarkably short in comparison with the cranium and with the width of the forehead. Generally speaking, its features are strongly reminiscent of those typical for Ewart's horse. On the other hand, however, the konik bears some resemblance to still another extinct horse, the steppe tarpan (Equus caballus gmelini Ant.). The structure of the cheek teeth, and especially the width of the chewing surface as well as the simplicity of the enamel patterns, point to the oriental origin of the konik. The tarpan resembled the mouse-gray Bilgoray pony in its colour, its short dished face and some other marks,

2 but differed in its lighter build, higher and more slender limbs; it also had a shorter and erect mane and no forelock. Taking all this into account, $\mathrm{Ve}$.

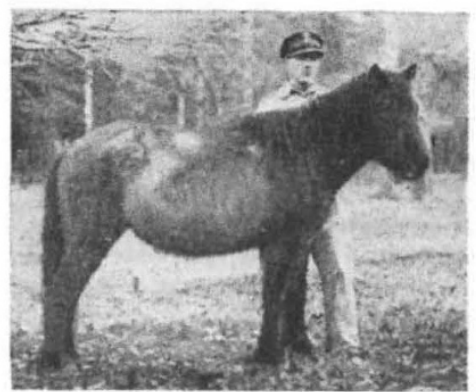
tulani arrived at the conclusion that the konik must be related to two varieties, the 3 wild steppe tarpan, extinct at the end of the last century, and a second, unknown variety which possessed the features of the "forest horse' of Ewart. $\mathrm{He}$ therefore introduced a new name for the Polish konik, the 'forest tarpan' or Equus gmelini Ant. forma silvatica, and he pic. tures the origin of the konik in the following manner.

With the onset of steppe conditions in Europein the glacial period and later-the steppe tarpan spread from the

(1) THE BILGORAY "KONIK", WITH THE CHARACTERISTIC BLACK STRIPE ALONG THE BAOK. (2) The stalion "TREF" IN AUTUMN, BeFORE TURNINg WHITE. (3) THE MARE "CZAJKA" IN AUTUMN. (4) THE MARE "CraJKA"'IN WINTER. (5) THE STALLION “TREF" IN WINTER.
Poznan, and also later by Prof. S. Hiller, of the University of Wilno (Vilna).

The konik is a small domesticated peasant-horse common in the district of Bilgoray, about lat. $50 \frac{1}{2}^{\circ} \mathrm{N}$. and long. $223^{\circ} \mathrm{E}$. It is of a mouse-grey colour with a black stripe along the back from the mane to the tail. It can live remarkably long and still retain its vigour. Indeed, Vetulani reported having seen a pony still hard at work at the age of twenty-six years. The konik differs from the steppe horse in several aspects, having well-rounded body lines, an abundant mane and tail, relatively short limbs, a small height, a characteristic 'dished' or concave steppe bordering on the Black Sea to central and north-west Europe. However, the dry steppe climate did not last for ever. Gradually it became moister, and forests replaced the great grassy regions. The tarpan, an animal adapted to the conditions prevailing in the vast prairies, had to retreat step by step from the north-west to the Black Sea regions of its ancestors, where it remained as a living wild animal until 1880 . In that fatal year the last tarpan lost its life after a fierce chase by hunters (Antonius). Of the tarpans which did not return to the Black Sea shores, some must have lost their lives because of the severe weather con- 
ditions. Others, more persistent and hardier, became inured and adapted themselves to the new conditions of life in the forest, undergoing gradually modifications in their bodies and developing at last into the new forest horse. Fossil remains of the latter are found throughout all central and north-west Europe, together with the remains of other members of the forest fauna such as the red-deer, roe-deer, boar, wild cat and elk.

A close examination of these remains reveals striking differences from the original tarpan; a shorter face and shorter limbs, two peculiarities which we also find in the mouse-grey lconik as well as in some breeds of Scottish ponies. According to Ewart, "of a hundred Shetland ponies examined . . . twenty-five had most of the points of the Forest Variety". The two peculiar qualities, the brachycephaly and the micromely, are often thought to be connected with changes of the pituitary body. The hypophysis, which was of cord-form in the steppe tarpan type, became broader in the forest Bilgoray pony; the basis of the gland became flatter and developed a depression in the anterior part. Corresponding to this the sella turcica has changed also. From a regular pit it became irregular, with a convexity in the anterior part. In its inner structure the pituitary body of the forest konik shows a reduced amount of the glandular substance of the anterior lobe. According to Vetulani the climatic influences induced these changes in the hypophysis first, and the changes in muscular tissue followed in consequence. A strong development of the muscles with thicker muscular fibres and a higher content of the intramuscular connective and adipose tissue must have had a decisive influence on the bones.

Historical records show that the district which was inhabited originally by the wild forest horse, from which later the domesticated Bilgoray pony developed, was the Great Forest of Bialowieza, about lat. $523^{\circ} \mathrm{N}$. and long. $24^{\circ} \mathrm{E}$. This famous forest was visited in the eighteenth century by the Frenchman Hacquet, who saw the living wild forest horse with its short and erect hair of the mane and described it in his work published in 1794. The nineteenth-century Polish author Kożmian records that the wild forest horse of Bialowieza was brought at the end of the eighteenth century into a private forest zoo-park of Count Zamoyski near Bilgoray. One winter, at the beginning of the nineteenth century, when the cold was uncommonly severe, the horses, until then living free, were captured and distributed among peasants of the neighbouring villages, where, tamed and crossbred, they gave rise to the mouse-grey peasant ponies, a considerable number of them retaining the pure blood of their wild ancestors.

In 1936 Vetulani made an attempt to breed the forest horse back to its wild state. Among the animals which were brought back to the Great Forest of Bialowieza, a Polish national park, were the stallion "Tref" and the mare "Czajka", both of which had the remarkable and unique property of turning white in winter in a manner characteristic for certain other animals such as the hare, grouse and ermine. Every winter they changed the mouse-grey summer coat, distinguished by the black stripe on the back, into a snow-white coat, only the face, fetlocks, mane and tail retaining the dark colour.

After three years of breeding the number of horses in the Bialowieza Park rose to eighteen, out of which eight have been born free in the forest. Some of them inherited the property of becoming white in winter. According to Vetulani, the enigmatic wild white horse described by Herodotus as grazing in the northern marshy land may well have been the Polish wild pony grazing in the Polesie bogs situated close to the Bialowieza Forest.

It may be regarded now as definitely established that: (1) the 'forest horse' postulated by Ewart existed in olden times as a wild animal in many a forest of north-west and central Europe ; (2) its last true wild descendants lived in the Great Forest of Bialowieza in Poland until the latest decades of the eighteenth century; and (3) some of the living wild forest horses were brought into a forest park and were later domesticated and to a certain degree cross-bred.

\section{HIGH-CONCENTRATION HYDRO- GEN CYANIDE FUMIGATION OF FUNGI AND BACTERIA}

\section{By $D_{R}$. N. POLUNIN}

Department of Botany, University of Oxford

$T$

THE highly toxic effects of hydrogen cyanide on animals are almost proverbial, and it is now well known that its main action causing their death is through interference with the respiratory enzymes ${ }^{1,2}$. Since these systems appear in general to be similar in animals and plants (including yeasts and bacteria ${ }^{3}$ ), the chief of them being found in representatives from all of the plant and animal phyla ${ }^{4}$, it might be expected that exposure to hydrogen cyanide would also kill plants easily. So far is this from being the case that hydrogen cyanide 'fumigation' is commonly employed as a means of killing insect pests on greenhouse plants which are little if at all adversely affected by the process; it is also extensively used in plant quarantine and against scale insects of citrus trees ${ }^{5}$. Even as it appears that a high rate of respiration is more important than the size factor in determining the susceptibility of different animals to the higher concentrations of hydrogen cyanide ${ }^{6}$, so it now seems likely that the usually greater resistance of plants to hydrogen cyanide is largely bound up with their generally much slower rate of metabolic activity.

Fungi and bacteria being "amongst the most actively respiring plants", one might have expected them to be relatively easily affected by hydrogen cyanide were it not, perhaps, for their frequently high content and rate of turnover of sulphur 3,8 . For, in low concentrations, hydrogen cyanide, even if application is prolonged, may have little or no ill effect upon living organisms, owing to its being rapidly "converted into harmless combinations with the aid of sulphur supplied by compounds of albumen"s. However this may be, and in spite of the fungicidal and bactericidal propertios of gaseous hydrogen cyanide being "extremely poor" in such concentrations and over such times of application as have usually been tried ${ }^{5,9}$, the following observations show that in heavy doses hydrogen cyanide can be lethal to both colonies and spores (or other disseminules) of such moulds and bacteria as were to be found in the air of two rather dusty rooms. Considering the effect of fairly high concentrations of the gas on green plants ${ }^{5,10}$ this was indeed to be 